\title{
MNEs as border-crossing multi-location enterprises: The role of discontinuities in geographic space
}

\author{
Sjoerd Beugelsdijk ${ }^{1}$ and \\ Ram Mudambi ${ }^{2}$ \\ ${ }^{1}$ University of Groningen, Groningen, The \\ Netherlands; ${ }^{2}$ Temple University, Philadelphia, \\ USA \\ Correspondence: \\ R Mudambi, Department of Strategic \\ Management, Fox School of Business, \\ Temple University, Philadelphia \\ PA 19122, USA. \\ email: ram.mudambi@temple.edu
}

\begin{abstract}
Spurred by the classic work of Dunning, MNE location has become the focus of a growing body of research in the field. In this paper we argue that international business (IB) research examining the spatial dimension has serious weaknesses, stemming from its traditional assumption of the country as the location unit of analysis. While border-crossing remains the key research context of IB, placing it within a general spatial framework that recognizes both international and subnational spatial heterogeneity opens up vast new vistas for research. Analyzing MNEs as border-crossing multi-location enterprises allows the researcher to distinguish between (discrete) border effects and (continuous) distance effects and undertake a more fine-grained analysis of location. Within such analysis national borders may appear as qualitative discontinuities in space, that is, points at which spatial heterogeneity changes abruptly. However, subnational spatial heterogeneity is often the characteristic that drives firm strategy as MNEs decide to locate in particular agglomerations and not at random locations within a country. The complex firms that IB scholars study typically include multiple units within the same country, so that a complete analysis requires considering both subnational distance effects as well as international border effects.
\end{abstract}

Journal of International Business Studies (2013) 44, 4I3-426. doi: I0. I 057/jibs.20 I 3.23

Keywords: multi-location enterprise; spatial discontinuities; border effects; distance effects

\section{INTRODUCTION}

International business (IB) and economic geography (EG) share a common interest in the study of firms that transcend geographic space. However, these two literatures approach this topic from different starting points and have consequently developed different strengths over the years. IB scholars have developed a sophisticated understanding of the economic organization of a geographically dispersed enterprise (Cantwell, 2009). Using an archetypical lens, this translates (roughly) into the $\mathrm{O}$ (ownership) and I (internalization) dimensions of Dunning's (1998, 2009) eclectic OLI paradigm. In contrast, IB scholars' understanding of both place and space remains relatively underdeveloped, since these are primarily geographic concepts (Beugelsdijk, Mudambi, \& McCann, 2010; McCann \& Mudambi, 2005). Location (L) in IB is almost always conceptualized and operationalized at the country level. Indeed, the very term "IB" invokes the nation-state as the 
unit of analysis. There are many reasons for this approach, including the historical role of national borders, the importance of national governments in international trade, the importance of national institutions in the formulation of business strategy and decision making and last, but not least, the availability of data.

It follows that the IB literature tends to view spatial variation in terms of distance between countries. Spatial heterogeneity exists in IB to the extent that countries differ in terms of their cultural and institutional framework, level of economic development and availability of resources. This distance is generally related to economic and business realities at the macro level (e.g., trade flows) as well as the micro level (e.g., the liability of foreignness). A familiar IB model that integrates these levels the firm on the one hand and the country on the other - is (Dunning \& Lundan, 2008; Rugman $1981,2005)$ the matrix of firm specific vs country specific advantages. Despite the presence of individual-level constructs such as cognitive distance, spatial variation in IB is often presented, analyzed and measured as a multidimensional, country-level construct (Beugelsdijk, 2011).

The main interest of economic geographers is the $\mathrm{L}$ (location) dimension of the eclectic paradigm that may be unpackaged into "place" and "space" (Beugelsdijk et al., 2010; McCann, 2011). Place refers to the geographic unit of analysis and is not restricted to the level of the country. Space, in the most general sense that we wish to develop and extend here, refers to any characteristic that generates variation and heterogeneity among places. Historically, the study of subnational social, economic and political variation was focused on a comparison of regional units as defined by their administrative borders, like states or counties, but also including units defined by policymakers (e.g., the Metropolitan Statistical Areas in the United States and so-called NUTS regions in the European Union). As in the case of $\mathrm{IB}$, one obvious reason for the use of such units is that government and other data collection agencies use them. However, with rising technological complexity, firms (as well as networks of firms) often cross the administrative boundaries of these units. This has led geographers to study the symbiotic relationship between firms and their regional environment, in what has been dubbed the "relational turn" in EG (Beugelsdijk, 2007; Dicken \& Malmberg, 2001; Henderson, Dicken, Hess, Coe, \& Yeung, 2002; Yeung, 2005). Approaching firm organization from these perspectives points to a fertile arena within which both IB and EG can jointly develop a more holistic understanding of economic activity dispersed across space (Cantwell, 2009; Iammarino \& McCann, 2013).

The international dimension in EG is present to the extent that national borders do fulfill an important role, yet not as definitively as in IB (McCann \& Mudambi, 2004). Borders are studied as a special case of heterogeneity among places or locations, and they form an aspect of a broader conceptualization of spatial variation. Although a construct such as the liability of foreignness is not used in EG, the social and economic meaning of borders for firms is addressed. In fact, the Journal of Borderland Studies is a geography journal that specifically addresses this role of national borders.

Our objective in this overview is to integrate the strengths of these two mature fields to advance our understanding of both firms and locations. Since we are primarily addressing IB scholars, we look at EG and what economic geographers can tell us about the notion of spatial variation. As IB research typically involves multilevel analysis, spatial variation can be found at both the macro and micro levels of economic activity. At the macro level, spatial variation takes the form of various distance metrics that differ qualitatively, as we will argue, depending on whether the context is international or subnational. At the micro level, it centers on the firm, its location and its linkages across space within and between countries. As we will argue below, in order to advance the IB research agenda, it is critical to incorporate the relevant aspects of within-country variation and integrate these with those of between-country variation.

We strongly believe that incorporating relevant insights on subnational spatial variation from EG into the modern theory of the MNE will bring us closer to what Casson (1987: 1) once described as "a general theory of the enterprise in space." In our view, such a general theory centers on recognizing the distinction between spatial heterogeneity that arises in the subnational context and spatial discontinuities that arise at national borders. Note that we are not arguing that nation-states do not matter - quite the contrary (McCallum, 1995; Sassen, 2000). Our argument is composed of two related points. First, we posit that subnational spatial variation should be added to the analysis, not that international spatial variation should be ignored or downplayed. Second, borders should be viewed as (discrete) discontinuities in space, so that they can 
be analyzed in the same models with (continuous) subnational spatial heterogeneity. This means moving away from the "step function" approach used in the vast majority of IB studies, whereby subnational spatial heterogeneity is set at zero.

At the macro level, this implies that existing distance research in IB needs to move beyond between-country measures like foreign direct investment (FDI) stocks and flows and begin incorporating within-country variation while simultaneously developing a more precise theory on the effects of space. At the micro level it implies that clustering and agglomeration effects, the thickness of local linkages and the nature of global linkages need to be taken into account (Goerzen, Asmussen, \& Nielsen, 2013; Lorenzen \& Mudambi, 2013). Only through the combined insights of IB and EG can we fully understand the complex interplay between place, space and organization (Beugelsdijk et al., 2010).

\section{SPATIAL VARIATION IN IB: DISTANCE BETWEEN COUNTRIES VS WITHIN-COUNTRY VARIATION}

The dominant conceptualization of spatial variation in IB is by means of between-country distance measures based on country-level means. Starting with geographic distance, IB scholars now include a variety of distances measures like economic, cultural, administrative, language, religious and institutional, to mention a few (Berry, Guillen, \& Zhou, 2010; Zaheer, Schomaker, \& Nachum, 2012). Subsets of these distance measures have been related to FDI (Slangen \& Beugelsdijk, 2010), location decisions (Berry et al., 2010), corporate social responsibility (Campbell, Eden, \& Miller, 2012), exports (Beugelsdijk, Hennart, \& Slangen, 2011), entry mode decisions (Slangen \& Hennart, 2008) and many more. In the broader literature, economists have recently developed measures of genetic and somatic distance and related those to trade, FDI and foreign portfolio investment (Guiso, Sapienza, $\&$ Zingales, 2009).

A common denominator of all these distance measures is that they are based on a difference of means between the home and host country. Economic distance is often measured as the difference between the mean GDP per capita of the home and the mean GDP per capita of the host. Cultural distance is calculated as the difference between the mean values of the home population and the mean values of the host population (often based on Hofstede, 1980). Geographic distance is often measured as the great circle distance from the geographic center of each country pair (Berry et al., 2010) or as the distance between capital cities (Slangen \& Beugelsdijk, 2010). In recent years, the perception in IB has been that the analysis of spatial variation can be improved simply by adding new distance dimensions to the set of existing ones. However, the theoretical and empirical value of piling on more and more distance dimensions is limited for two reasons. First, it has been shown that many of the commonly used distance dimensions are highly correlated (Berry et al., 2010). Second, when many of these highly correlated distance dimensions are included in the analysis, it is difficult to untangle their individual effects (Zaheer et al., 2012).

Instead of adding more distance dimensions, we suggest changing the nature of existing distance dimensions. The EG perspective helps us redirect research on spatial heterogeneity by pointing to the importance of spatial variation that is present within countries. Firms do not locate in country centers, nor do they employ workers that represent country averages. In fact, the types of subnational spatial variation ignored by analyses based on country averages are precisely what shape firm location strategies (Dai, Eden, \& Beamish, 2013; Gertler, $1995,2003)$. We suggest moving from the current dominance of analyses based on country means to a study of IB activities where the complex intermingling of different geographic scales (global, supra-regional, national and subnational) is taken into account. As Dicken, Kelly, Olds, and Yeung (2001: 95) put it, "a distinctive feature of contemporary capitalism is to operate on multiple scales, but none of these scales should, in themselves, be considered a privileged level of analysis."

Therefore, the inclusion of within-country spatial variation is an important next step to proxy for the actual spatial distance firms need to bridge (Goerzen et al., 2013). In fact, the unrealistic assumption of subnational spatial homogeneity is one of the bases of Shenkar's (2001) criticism of the widely used cultural distance index. Given the premise in IB that firms minimize distances to reduce the liability of foreignness (Berry et al., 2010), the presence of within-country variation in home and host countries raises the question of how to incorporate the distance within countries, and how to make those internal distances consistent with the traditionally used international distance measures. Internationalizing firms have very specific objectives that may be related to their value chains (Cantwell \& Mudambi, 2005; Schmitt \& Van 
Biesebroeck, 2013). Paraphrasing the well-known Dunning categorization, these may be itemized as market-seeking, asset-seeking and efficiencyseeking (Dunning \& Lundan, 2008). The first two are mainly based on competence considerations to buttress the firm's specialized activities in upstream $\mathrm{R} \& \mathrm{D}$ and downstream marketing. The third is typically based on cost concerns and is undertaken primarily to improve the firm's standardized, repetitive activities (Mudambi, 2008).

Market-seeking firms do not target the average culture but try to find a relevant segment of the market that their competencies are best suited to serve. A Western MNE such as Starbucks mainly targets customers with Western-like values and lifestyles, so that the relevant yardstick when moving to China is not the average GDP per capita in China, but that of Shanghai and Hong Kong. Jollibee, the largest food chain in the Philippines, mainly targets Filipinos abroad, which defines the relevant population centers (Verbeke, 2009). Latin American banks are overrepresented in Miami, Florida, due to the city's large and fast growing Hispanic community "with unique demands and needs" (Miller, Thomas, Eden, \& Hitt, 2008: 651). Even large MNEs with predominantly global strategies often target specific customer segments within countries, recognizing that "groups of consumers in different countries often have more in common with one another than with other consumers in the same country" (Steenkamp \& Hofstede, 2002: 186).

In a similar vein, asset-seeking firms typically focus on agglomerations or clusters that contain the resources that are most relevant to their needs (Goerzen et al., 2013). To understand the role of geographic distance in knowledge-intensive IT-related FDI flows to the United States by measuring the distance between the capital city of the home country and Washington DC (or the geographic center of the United States) does not come close to capturing the importance of Silicon Valley as a prime location for IT-related knowledge-based activities. The same is true for an asset-seeking entrant anywhere in the world, so that biotech firms entering the United Kingdom may choose to locate in Cambridge, rather than London (Cooke, 2001), and automotive firms entering India may choose to enter Pune or Chennai rather than Mumbai or Delhi (Kumaraswamy, Mudambi, Saranga, \& Tripathy, 2012). In all these cases, the subnational location adds critical information to the national location decision, so that focusing solely on the international dimension is not incorrect, but seriously incomplete.
Finally, efficiency-seeking firms are attracted to particular subnational regions for reasons that relate to cost, but that may stem from a variety of historical or institutional reasons. For example, by locating their US production plants on Rhode Island in the 1920s, French woolen textile manufacturers could hire French-Canadian labor that had migrated to the region (Wilkins, 2004). More recently, many Japanese MNEs' US production affiliates use strict selection procedures, hiring only those US workers whose values allow them to cope with Japanese production and management practices (Florida \& Kenney, 1991).

Economic geographers have conceptualized distance-related subnational variation in terms of proximity. Partly triggered by the observation that knowledge spillovers are spatially bounded (Jaffe, Trajtenberg, \& Henderson, 1993 is the classic study; see D'Este, Guy, \& Iammarino, 2012 for a recent overview of this vast literature), economic geographers have related geographical proximity to innovation and developed a large variety of territorial (read: subnational) innovation models (Moulaert \& Sekia, 2003). In a process similar to the one we described above relating to distance research in IB, the focus on proximity in EG has led to the successive development of different dimensions of proximity. For example, building on geographical proximity, Boschma (2005) discusses cognitive, organizational, social and institutional proximity. Thus, one natural path to enriching distance research in IB is by taking a closer look at the proximity literature in EG.

\section{BORDERS AS DISCONTINUITIES IN SPACE}

The distinction between subnational and international distance immediately allows us to make a careful distinction between border effects and distance effects. Border and distance effects are not the same. Although distance and the liability of foreignness are often used interchangeably in IB, they are theoretically distinct concepts. The liability of foreignness as originally described by Hymer (1976), as the cost of doing business abroad is a discrete border effect, whereas distance is by definition a concept with a continuous measure.

Distinguishing between border and distance effects, Ghemawat (2011) claims that while national border effects have come down, distance effects have increased. The reduced importance of national borders does not imply that subnational regional borders have taken over and increased in importance. National borders still serve as points 
where spatial transaction costs increase in a discontinuous manner (Beugelsdijk et al., 2010; McCallum, 1995; Sassen, 2000). We see national borders as discontinuities in geographic space or what Dicken et al. (2001: 96) refer to as a qualitative disjuncture. The implication of this way of conceptualizing spatial variation is that a firm with network linkages across national borders is not just another example of "acting at a distance" but a combination of discrete border effects and continuous distance effects. Measures of country distances used in IB pick up the extent of discontinuity (Schotter \& Beamish, 2013). Thus, the challenges and complexities faced (and overcome) by MNEs are underestimated when studies consider only border effects and ignore subnational distance effects. Further, the extent of discontinuity depends on the extent of subnational spatial heterogeneity.

Thus, a clear recommendation for future research exploring the spatial variation confronting internationalizing firms is to distinguish explicitly between border and distance effects. Consider the following highly simplified pedagogical example. In the figures, we depict the textbook MNE with a home in country B and FDI in country A that we unpack into a country headquarters (HQ) and an operating subsidiary. The typical IB study articulated at the country level would specify the geographic distance between the two parts of the firm as the distance between country centers, that is, the great circle distance XY. In most cases, country subsidiaries are treated as single entities (since the location unit of analysis is the country), and the country HQ and operating unit are concatenated. Clearly approximating the geographic distance between the firm's world HQ and its country operations with XY creates an error that increases, on average, with the sizes of the home and host countries. However, that is a relatively straightforward problem that can be dealt with by using more precise firm-level information.

More serious problems arise when IB studies add more and more dimensions of distance, all measured at the country level. These errors remain small when subnational variation is limited. However, in many cases, as subnational variation increases, the errors introduced by using border effects to measure distance can become severe. In our example, we pick one other dimension in addition to geographic distance and call it "economic" distance to illustrate our point (we could just as well have used cultural distance or any other distance metric). In Figure 1, subnational variation in the host country

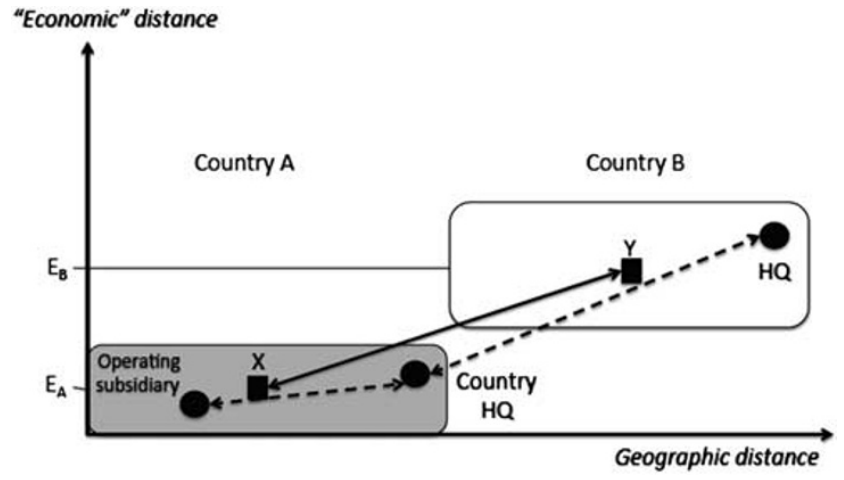

Figure 1 Relatively low sub-national spatial heterogeneity.

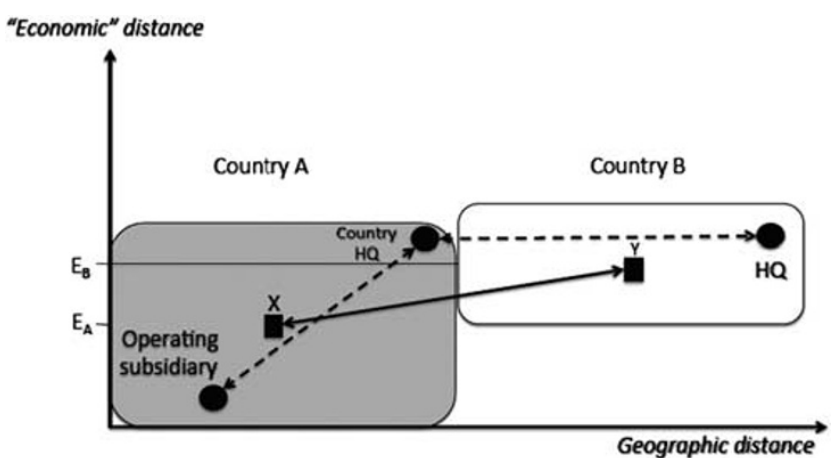

Figure 2 Relatively high sub-national spatial heterogeneity.

A is relatively low, so the economic distance between home and host, $\mathrm{E}_{\mathrm{A}} \mathrm{E}_{\mathrm{B}}$, is not a bad approximation of the economic distance between the home and host operations of the firm. However, consider Figure 2, where the subnational variation in the host country is quite large. The economic distance between home and host $\mathrm{E}_{\mathrm{A}} \mathrm{E}_{\mathrm{B}}$ is substantial, but smaller than the subnational variation between the host country units of the firm. In this case, the discontinuity in economic space does not occur at the border, but within the host country. In fact, the economic distance between the host country HQ and the world HQ at home is zero.

We argue that the situation in Figure 2 is likely to arise in many IB contexts. Many dimensions of distance between emerging economy hotspots and advanced economy HQ are quite small, so that the large differences in country-level averages are completely unrepresentative. Such anomalies appear in numerous recent studies of emerging economy contexts including mature sunset industries like steel (Ramamurti \& Singh, 2009), mature industries like autos (Kumaraswamy et al., 2012), creative 
industries like movies and information technology (Lorenzen \& Mudambi, 2013) and high-technology industries like pharmaceuticals and biotechnology (Yeolekar \& Mehta, 2007). The border effects do not pick up "the diversity of locational environments" that are appropriate for "the study of firm-location interactions" (Cantwell, 2009: 35). It is well known that most firm-location interactions occur within very narrow geographic confines (Dai et al., 2013; Jaffe et al., 1993).

Nor is this effect limited to the emerging economy context. Figure 2 could just as well apply to the case of two advanced economies. For instance, several measures of distance place the English-speaking Canadian city of Windsor closer to Detroit in the United States than to Frenchspeaking Montreal in Canada, and this affects the thick cross-border auto industry linkages in this part of North America (Klier \& McMillen, 2008), among many other economic and business realities. The problem we illustrate here grows worse as we introduce more and more border effects (economic, cultural, institutional, legal etc.) since the errors introduced by conflating them with distance effects grow exponentially.

These observations have led economic geographers to correct the distance measures they use. As a result, revised geographic distance measures are not based on distance between capital cities or the great circle distance, but they take the internal distance between consumers and producers within countries into account when testing for the role of distance between countries (Mayer \& Zignago, 2011). Recent studies show that the existing mean-based measures used in the literature overestimate effective distances and that this distance inflation is stronger the closer the two nations are to each other (e.g., Head \& Mayer, 2010). By taking the internal distance into account when assessing the role of international distances, distance can be contextualized, an approach which is in line with some recent suggestions in IB (Zaheer et al., 2012) that follow on earlier work in EG (Scott, 1996; for a survey see Iammarino \& McCann, 2013).

The theoretical recognition that within-country variation matters has led to the development of revised geographic distance measures that distinguish between border and distance arguments and incorporate both. The use of such measures has resulted in more precise estimates of the impact of geographic distance on trade and FDI (Iammarino \& McCann, 2013). Given the popularity and importance of aggregate distance proxies in IB, improvements similar to the one for geographic distance need to be developed for the other distance dimensions. This is not impossible, and sometimes it is related more to breaking path dependency than statistical or methodological complexity.

For example, when developing proxies for the potential fit between home and host country consumer preferences and purchasing power, median income differentials are a better measure than mean differentials. If we do not creatively improve our distance proxies and do a better job of grounding them in theoretical logic, we are likely to get the paradoxical result that undertheorized distance measures lead to overestimated distance results - as the above examples so vividly illustrate.

With the explicit distinction between distance and border effects and the consideration of withincountry spatial variation comes the need to better specify the theoretical mechanism linking a specific distance dimension to an outcome variable. IB scholars study internationalizing firms and MNEs in particular, thus examining a wide range of study variables including location choice, FDI amount, foreign sales, subsidiary performance and entry mode, to name a few. The existing IB literature tends to apply a common "less is better" principle to all dimensions of distance. However, different distance dimensions matter in different ways for different phenomena of interest. Economic geographers and international economists have shown that geographic distance plays a different role for what they call the intensive and the extensive margin of trade and FDI. The extensive margin refers to the (discrete) FDI location decision, while the intensive margin relates to the (continuous) amount of FDI (Chaney, 2008).

The current arguments in IB regarding distance effects often lump together a range of quite disparate issues, ranging from increased communication costs (cultural differences, cognitive distance), lack of customer fit (cultural differences), coordination across time zones (geographic distance), contracting complexities (institutional distance) and consumer purchasing power (economic distance). The underlying mechanism is not sufficiently spelled out, whereas this is exactly what theory is all about (Bello \& Kostova, 2012; Thomas, Cuervo-Cazurra, \& Brannen, 2011). As a result, distance measures are often made up of a set of items that are not based on the same theoretical argument. In an example that is by no means atypical, Berry et al. (2010) 
suggest measuring economic distance by a factor consisting of four items: the difference in GDP per capita, inflation rate and exports and imports as a percentage of GDP. GDP per capita differences (measuring differences in consumer welfare) may be relevant for the location choice of marketseeking firms, while trade as percentage of GDP (an openness measure) may be relevant for explaining the amount of efficiency seeking FDI.

For IB research to progress, it will be necessary to move from this first-generation distance research to modeling of spatial variation in a manner that carefully distinguishes between border and distance effects. In so doing it can identify precisely where spatial discontinuities arise and use these to develop theory. The development of more precise theoretical arguments will improve our theoretical and empirical understanding of place, space and the way firms organize themselves (Beugelsdijk et al., 2010; Zaheer et al., 2012).

\section{THE RELATIONSHIP BETWEEN SPATIAL COSTS AND ECONOMIC ACTIVITY}

Correctly measuring spatial costs is only the first step toward integrating space into an analysis of IB activity. When Dunning (1998: 45) called for more emphasis on location in the analysis of the MNE, he did not suggest that it be retrofitted to extant models, but rather that models be reformulated to recognize that "firm-specific assets have become mobile across natural boundaries." ${ }^{1}$ Such reformulations are sadly lacking in many IB attempts to incorporate location into an analysis of the MNE (see the Appendix for more on this).

In this context, one of the key weaknesses in IB theorizing is that authors typically assume that falling spatial costs between nodes imply an increased intensity of economic activity between those nodes. While not ideal, this is a forgivable omission when one is studying macro-level phenomena like trade flows and aggregate levels of FDI. However, much of IB research is undertaken at the firm level and here the assumption becomes much less tenable and can lead to serious errors.

The mechanisms whereby MNEs deal with the difficulties of leveraging knowledge and capabilities from spatially dispersed locations have been studied in great detail in IB. In this literature, the problem has been disaggregated into two distinct sub-problems: transferring knowledge and resources within the MNE and sourcing these from actors outside the MNE. The IB literature is stronger in terms of its analysis of first of these sub-problems.
Beginning with the work of Bartlett and Ghoshal (1989), a number of scholars have studied how MNEs combat the tendency of knowledge and resources to be internally "sticky" (Szulanski, 1996). This refers to the fact that transferring assets within the MNE from one subsidiary to another is a process dogged by a number of tricky problems.

It is impossible to do full justice to this vast literature here, except to note these difficulties arise from three fundamental causal bases: failures of ability, managerial biases and opportunistic behavior. The first heading encompasses the whole range of managerial limitations from bounded rationality to incomplete information (for an overview, see Mudambi, 2002). The second relates to issues arising from cognition and includes problems like the "not invented here" syndrome (Katz \& Allen, 1982) and "groupthink" (Kahneman, 2011). Finally, the third stems from agency relationships within the MNE (e.g., Mudambi \& Navarra, 2004).

The second sub-problem is addressed in a more sophisticated manner in EG where a large stream of literature now exists documenting that in addition to spatial costs (that can be minimized by proximity or co-location) there are significant social interaction costs that must be borne in order to actualize economic and business relationships (Cantwell \& Mudambi, 2011; Malmberg \& Maskell, 2002). Knowledge in clusters flows within defined social networks and is not "in the air" so to speak (Giuliani, 2007; Lorenzen, 2007). This means that the link between co-location and economic interaction cannot simply be assumed to be positive as in many IB studies. It is a complex relationship that requires careful and formal theorizing. But in order to do so, it is necessary in order to understand the mechanisms whereby MNEs source location-based advantages.

The social interaction costs within locations are not uniform but differ depending on the nature of the transacting entity. Recent research has shown that there is much more to these social interaction costs than the liability of foreignness (Zaheer, 1995), which simply assumes that they are higher for foreign firms as compared to domestic ones. This is one area where both the IB and EG literatures tend to assume that domestic actors are more locally embedded than subsidiaries of MNEs. For instance, Coe, Hess, Yeung, Dicken, and Henderson (2004) write that "local actors in specific regions (e.g., labor and the state) and non local actors in global production networks (e.g., 
TNCs and financial capital) are differentiated by their degree of territorial embeddedness." There is evidence that focusing on the difference between foreign and domestic actors in this context is often misleading for at least two sets of reasons.

First, it has been argued that in order to access local resources, subsidiaries need to embed themselves in local business networks (Andersson, Forsgren, \& Holm, 2002; Gertler \& Levitte, 2005; Heidenreich, 2012). The reason domestic firms have a lower cost of transacting and interacting locally is often because they are better embedded. The foreign-domestic comparison may really be picking up a difference between firms that are locally well embedded and those that are less so. The embeddedness of subsidiaries in the local business network is positively associated with their competence development (Andersson et al., 2001). In fact, when comparing foreign subsidiaries and domestic firms after controlling for the level of embeddedness, it has been shown that the former actually depend more heavily on local knowledge (Almeida, 1996). There are sound selection-based arguments as to why subsidiaries of foreign MNEs are, on average, more tightly enmeshed in high value local networks than domestic firms. ${ }^{2}$

Second, foreign subsidiaries differ in terms of how attractive local players perceive them to be. Recent evidence indicates that the foreign subsidiaries of MNEs that are industry leaders are able to tap into the best local resources, suggesting that they have low local social interaction costs, probably because they are desirable partners. In contrast, foreign subsidiaries of MNEs that are industry laggards are unable to tap into local resources and become dependent on their parent firms, suggesting that they have high local social interaction costs, as they may be viewed unfavorably as partners (Cantwell \& Mudambi, 2011).

Conversely, there is evidence that in many cases geographically dispersed units are able to work together to innovate and create value (Cantwell \& Santangelo, 1999; Mudambi, Mudambi, \& Navarra, 2007). Such interaction is becoming more common and encompasses a wider range of possibilities as the power of electronic networks increases (Malhotra, Majchrzak, \& Rosen, 2007). Digital communications and embedded technologies have big effects on the ways in which spatial costs and non-spatial transaction costs are interrelated, and this in turn has big effects on the global organization of production. In the case of Hollywood, Scott and Pope (2007) show how co-location and interaction across space (both local and global) help understand the changing nature of film production. Gathering all this evidence together it may be seen that co-location is neither necessary nor sufficient for economic interaction. The relationship between spatial costs and economic interaction is a nuanced one that requires careful modeling rather than blunt assumptions.

\section{THE WAY FORWARD: SPATIAL DISCONTINUITIES AND BORDER-CROSSING MULTI-LOCATION ENTERPRISES (MLES)}

Taking the EG perspective to an extreme, the multinational enterprise has been seen as a special case of the MLE. "The multi-establishment firm is at once functionally integrated and spatially dispersed. A special case of this type of firm is the multinational enterprise, which is in fact no more than a multi-establishment firm with the additional characteristic that some of its internal parts are located in different political jurisdictions" (Scott, 1986: 225). Indeed, once we drop the (often unstated) assumption that the location unit of analysis is the national state, the MLE becomes an MNE only when a national border appears between any two of its locations.

However, 50 years of IB research has taught us that borders matter greatly in various ways. This crucial role of borders ensures that the MNE is not simply a special case of the MLE. It means that IB scholars' interest in borders (read: spatial discontinuities) adds a crucial element to the MLE, such that the MNE and the MLE become different species. Indeed, one may quite convincingly argue that the MNE is an order of magnitude more complex than the MLE. Each national subsidiary of an MNE typically comprises multiple spatially dispersed units, so that it is effectively an MLE. In other words, the typical MNE is made up of numerous MLEs, each within a national context.

Moving from the MLE to the MNE is not just a matter of degree precisely because border effects are discontinuous (i.e., abrupt and qualitative differences) while distance effects are continuous (smooth quantitative differences). In fact, IB scholars' deep knowledge of how border effects affect firm (location) strategy can be effectively used to theorize on spatial discontinuities in general at different spatial scales, something that can also enrich contemporary EG. Spatial discontinuities can sometimes arise at the sub- and supra-national scale, and IB insights can often apply. 
Our framework also helps in formulating a response to the suggestion by some authors that the "big" questions that relate to border effects (explaining flows of FDI, understanding the nature and organization of the MNE and the internationalization of firms) have already been successfully answered (Buckley, 2002). It is true that IB has developed a deep knowledge of internationalizing firms, their (location) strategies and the economic organization of value added creation across national borders. However, our framework adds another layer of spatial complexity stemming from our ambition to integrate spatial discontinuities between nation-states and spatial heterogeneity within national boundaries in order to generate a complete picture of the location dimension of the MNE. This requires simultaneously analyzing distance and border effects. In our view, it is exactly this additional complexity - derived from our integration of IB and EG - that generates a host of fertile opportunities for future research in IB.

In particular, it opens up an enormous range of unexplored terrain regarding the complexity of the firm's subnational activities, and more importantly relating these to its multinational activities. Even within the simplicity of Figures 1 and 2, the firm's multi-location activities within country B can be related to the multinational control strategies of its world HQ in country A. For example, Dunning and Norman (1983) analyze how the functional roles of host country operations affect subnational location decisions. This is an early example of how a joint analysis of border effects and distance effects can shed light on the organization of complex firms that often include both international and subnational geographic dispersion. Other more recent examples are Mariotti, Piscitello, and Elia (2010), who show how the location behavior of MNEs is affected by local knowledge spillovers, and Kim, Delios, and $\mathrm{Xu}$ (2010), who study how organizational and geographic proximity affect subsidiary exit rates. Such analyses from EG are however rare within the extant IB literature.

What we describe in this paper is the natural pattern of scientific advance - integrating insights from diverse disciplines and then developing specialist expertise (Mudambi, Hannigan, \& Kline, 2012). Relativity did not negate Newtonian mechanics but it merely specified the framework within which it works and where it breaks down. However, it completely changed our worldview and led to new insights that could not have been reached starting from a Newtonian view of the universe (Feynman, 1988). Similarly, conceptualizing the MNE as a border-crossing MLE allows the researcher to treat distance in a much more nuanced way, incorporating both subnational distance measures and border effects so that the full complexity of the firm can be analyzed. We recognize that using the formulation of the border-crossing MLE rather than the MNE may often lead to only small corrections (as the corrections made by relativity are trivial in most commonplace situations). However, philosophically the move to a new paradigm is momentous and may lead to entirely new insights that we cannot now conceptualize (Talbott, 2007).

In developing the border-crossing MLE, we expand the remit for the field of IB by defining a three-dimensional framework of place (localized agglomerations of economic activity), space (incorporating both smooth changes in variety as well as qualitative discontinuities) and organization (the activities of firms). Firms organize resources from places and integrate them across space in order to create value. Within this framework, the bordercrossing MLE can be viewed as a firm that has the unique ability to deal with spatial discontinuities.

Proceeding in this manner allows us to answer the recent call to move beyond the atheoretical approach used in IB research streams (Bello \& Kostova, 2012) like MNE location and multinationality-performance (Zaheer et al., 2012). Hennart (2007) criticizes the multinationality-performance literature for its lack of theoretical grounding, and one of his strong criticisms relates to plant size and minimum efficient scale. Hennart's criticism is easy to follow once we conceptualize the MNE as a border-crossing MLE, as he raises the crucial question, does performance variation come from multiple national contexts or multiple locations? Hennart's argument is weighted in favor of multiple locations, not multiple national contexts, but the empirical evidence here is certainly not conclusive. Similarly, location by firms is very often driven by the properties of subnational entities like cities and clusters. From our conceptualization of the bordercrossing MLE such location choices within countries logically follow from the recognition that spatial discontinuities can also be found within countries.

The IB research community has been researching the MNE for over 50 years. It has developed an impressive compendium of knowledge on this crucial business phenomenon. However, this rich research program is reaching the limits of what can 


\section{ACKNOWLEDGEMENTS}

be achieved under the constraining assumption that fixes the location unit of analysis at the level of the nation-state. In moving forward to analyze the border-crossing MLE, IB scholars can add their extraordinary knowledge of firm organization to economic geographers' and regional scientists' sophisticated knowledge of place and space. Taken together, this approach offers the best hope for IB to rekindle its research fires and get us closer to Casson's (1987) idea of a general theory of the enterprise in space.

\section{SOME NEW BEGINNINGS}

All of the papers in this special issue contain different approaches to the research agenda that we have outlined. One key requirement for advancement is moving beyond the nation-state as the unit of locational analysis. Three papers address this issue explicitly, one focusing on global cities (Goerzen et al., 2013) and one on subnational regional variation (Dai et al., 2013; published in a subsequent issue), while the other examines the effects of supra-national scale (Flores, Aguilera, Mahdian, \& Vaaler, 2013). A second requirement is developing an understanding of the drivers of spatial outcomes. Schmitt and Van Biesebroeck (2013) take a very in-depth look at the role of proximity in MLE organization, seeking to understand its underlying strategic drivers. Alcacer, Dezső, and Zhao (2013) analyze the complexity of the interdependence of the strategic activities in one subnational domain on those in another subnational domain. Finally, a third requirement is the recognition that spatial distance measures have an effect on firm decisions through the perceptions and decision making of individual managers (Schotter \& Beamish, 2013). Hence, as in strategy in general, the microfoundations of spatial perception are critical to understanding outcomes (Piscitello, 2011).

\section{REFERENCES}

Alcacer, J., Dezsó, C., \& Zhao, M. 2013. Firm rivalry, knowledge accumulation, and MNE location choices. Journal of International Business Studies, 44(5): 504-520.

Almeida, P. 1996. Knowledge sourcing by foreign multinationals: Patent citation analysis in the US semiconductor industry. Strategic Management Journal, 17(Winter Special Issue): 155-165.

Andersson, U., Forsgren, M., \& Holm, U. 2001. Subsidiary embeddedness and competence development in MNCs: A multi-level analysis. Organization Studies, 22(6): 1013-1034.

Andersson, U., Forsgren, M., \& Holm, U. 2002. The strategic impact of external networks: Subsidiary performance and competence development in the multinational corporation. Strategic Management Journal, 23(11): 979-996.

Bartlett, C. A., \& Ghoshal, S. 1989. Managing across borders: The transnational solution. Boston: Harvard Business School Press.
The first author would like to thank the Netherlands Organization for Scientific Research for their financial support (VIDI-Grant 452-11-010). We thank John Cantwell, Allen Scott, Simona lammarino and anonymous reviewers for their insightful comments and suggestions. The usual disclaimer applies.

\section{NOTES}

${ }^{1}$ Notice that even in this classic article, Dunning writes of "natural" and not national boundaries, indicating an awareness of the distinction between border and distance effects discussed in the previous section.

${ }^{2}$ It has been long documented that firms that are able to overcome the costs associated with crossing borders (i.e., MNEs) are not a random set of firms but possess firm-specific mobile assets that can be deployed to generate location-neutral competitive advantages (Morck \& Yeung, 1991). The outcome of this selection is the finding documented in the socalled "insourcing" literature that on average, subsidiaries of MNEs have significantly higher levels of R\&D, wages, high-skill employment (Beugelsdijk, Brakman, Van Ees, \& Garretsen, 2013; Slaughter, 2004) and connections to local high-technology actors (Cantwell \& Mudambi, 2011; Frost, 2001) than domestic firms.

${ }^{3}$ The software used is called QDA minor-Wordstat. We include the search terms border, borders, distance, distances and distant. For a more detailed description of the procedure we refer to Em (2011). Note that a similar picture emerges when counting the number of articles in which these words appear. Detailed results are available upon request from the authors. We thank Laetitia Em for her excellent research assistance in the data analysis that appears in this Appendix. We also refer the interested reader to the more detailed analysis in Em (2011).

Bello, D. C., \& Kostova, T. 2012. From the Editors: Conducting high impact international business research: The role of theory. Journal of International Business Studies, 43(6): 537-534.

Berry, H., Guillen, M., \& Zhou, N. 2010. An institutional approach to cross-national distance. Journal of International Business Studies, 41(9): 1460-1480.

Beugelsdijk, S. 2007. The regional environment and a firm's innovative performance: A plea for a multi-level interactionist approach. Economic Geography, 83(2): 181-199.

Beugelsdijk, S. 2011. Location specific advantages and liability of foreignness: Time, space and relative advantage. In C. G. Asmussen, T. Devinney, T. Pedersen, \& L. Tihanyi (Eds), Advances in International Management: 181-210. Amsterdam: JAI Press. 
Beugelsdijk, S., Brakman, S., Van Ees, H., \& Garretsen, H. 2013. Firms in the international economy: Firm heterogeneity meets international business. Cambridge, MA: MIT Press.

Beugelsdijk, S., Hennart, J. F., \& Slangen, A. 2011. The impact of cultural distance on US arm's length exports: An international business perspective. Management International Review, 51(6): 875-896.

Beugelsdijk, S., Mudambi, R., \& McCann, P. 2010. Place, space and organization: Economic geography and the multinational enterprise. Journal of Economic Geography, 10(4): 485-493.

Boschma, R. 2005. Proximity and innovation: A critical assessment. Regional Studies, 39(1): 61-74.

Buckley, P. J. 2002. Is the international business research agenda running out of steam? Journal of International Business Studies, 33(2): 365-373.

Campbell, J., Eden, L., \& Miller, S. R. 2012. Multinationals and corporate social responsibility in host countries: Does distance matter? Journal of International Business Studies, 43(1): 84-106.

Cantwell, I. A. 2009. Location and the multinational enterprise. Journal of International Business Studies, 40(1): 35-41.

Cantwell, J. A., \& Mudambi, R. 2005. MNE competencecreating subsidiary mandates. Strategic Management Journal, 26(12): 1109-1128.

Cantwell, J. A., \& Mudambi, R. 2011. Physical attraction and the geography of knowledge sourcing in multinational enterprises. Global Strategy Journal, 1(3-4): 206-232.

Cantwell, J. A., \& Santangelo, G. 1999. The frontier of international technology networks: Sourcing abroad the most highly tacit capabilities. Information Economics and Policy, 11(1): 101-123.

Casson, M. 1987. The firm and the market: Studies in multinational enterprises and the scope of the firm. Cambridge, MA: MIT Press.

Chaney, 2008. Distorted gravity: The intensive and extensive margins of international trade. American Economic Review, 98(4): 1707-1721.

Coe, N. M., Hess, M., Yeung, H., Dicken, P., \& Henderson, J. 2004. 'Globalizing' regional development: Global production networks perspective. Transactions of the Institute of British Geographers, 29(4): 468-484.

Cooke, P. 2001. Biotechnology clusters in the UK: Lessons from localization in the commercialization of science. Small Business Economics, 17(1-2): 43-59.

Dai, L., Eden, L., \& Beamish, P. W. 2013. Place, space and geographical exposure: Foreign subsidiary survival in conflict zones. Journal of International Business Studies, advance online publication 18 April. doi: 10.1057/jibs.2013.12.

D'Este, P., Guy, F., \& lammarino, 2012. Shaping the formation of university-industry research collaborations: What type of proximity does really matter? Journal of Economic Geography, first published online 2 May. doi: $10.1093 / \mathrm{jeg} / \mathrm{lbs} 010$.

Dicken, P., Kelly, P. F., Olds, K., \& Yeung, H. 2001. Chains and networks, territories and scales: Towards a relational framework for analyzing the global economy. Global Networks, 1(2): 89-112.

Dicken, P., \& Malmberg, A. 2001. Firms in territories: A relational perspective. Economic Geography, 77(4): 345-363.

Dunning, J. H. 1998. Location and the multinational enterprise: A neglected factor? Journal of International Business Studies, 29(1): 45-66.

Dunning, J. H. 2009. Location and the multinational enterprise: John Dunning's thoughts on receiving the lournal of International Business Studies 2008 Decade Award. Journal of International Business Studies, 40(1): 20-34.

Dunning, J. H., \& Lundan, S. 2008. Multinational enterprises and the global economy, (2nd edn). Northampton, MA: Edward Elgar.

Dunning, J. H., \& Norman, G. 1983. The theory of the multinational enterprise: An application to multinational office location. Environment and Planning A, 15(5): 675-692.
Em, L. 2011. Disentangling the different concepts of distance: A lexicographic exploration of the past 20 years of the Journal of International Business Studies. Paper presented at Academy of International Business Annual Conference, Nagoya, Japan.

Feynman, R. 1988. QED: The strange theory of light and matter. Princeton, NJ: Princeton University Press.

Flores, R., Aguilera, R., Mahdian, A., \& Vaaler, P. 2013. How well do supra-national regional grouping schemes fit international business research models? Journal of International Business Studies, 44(5): 451-474.

Florida, R., \& Kenney, M. 1991. Transplanted organizations: The transfer of Japanese industrial organization to the US. American Sociological Review, 56(3): 381-398.

Frost, T. 2001. The geographic sources of foreign subsidiaries' innovations. Strategic Management Journal, 22(2): 101-123.

Gertler, M. S. 1995. 'Being there': Proximity, organization, and culture in the development and adoption of advanced manufacturing technologies. Economic Geography, 71(1): 1-26.

Gertler, M. S. 2003. Tacit knowledge and the economic geography of context, or the undefinable tacitness of being there. Journal of Economic Geography, 3(1): 75-99.

Gertler, M. S., \& Levitte, Y. M. 2005. Local nodes in global networks: The geography of knowledge flows in biotechnology innovation. Industry and Innovation, 12(4): 487-507.

Ghemawat, P. 2011. The World 3.0: Global prosperity and how to achieve it. Cambridge, MA: Harvard Business Review Press.

Giuliani, E. 2007. The selective nature of knowledge networks in clusters: Evidence from the wine industry. Journal of Economic Geography, 7(2): 139-168.

Goerzen, A., Asmussen, C. G., \& Nielsen, B. 2013. Global cities and multinational enterprise location strategy. Journal of International Business Studies, 44(5): 427-450.

Guiso, L., Sapienza, P., \& Zingales, L. 2009. Cultural biases in economic exchange. Quarterly Journal of Economics, 124(3): 1095-1131.

Head, K., \& Mayer, T. 2010. Illusory border effects: Distance mismeasurement inflates estimates of home bias in trade. In S. Brakman \& P. van Bergeijk (Eds), The gravity model in international trade: Advances and applications: 165-192. Cambridge: Cambridge University Press.

Heidenreich, M. 2012. Innovation and institutional embeddedness of multinational companies. Cheltenham: Edward Elgar.

Henderson, I., Dicken, P., Hess, M., Coe, N., \& Yeung, H. 2002. Global production networks and the analysis of economic development. Review of International Political Economy, 9(3): 436-464.

Hennart, J.-F. 2007. The theoretical rationale for a multinationality/performance relationship. Management International Review, 47(3): 307-317.

Hofstede, G. 1980. Culture's consequences: International differences in work-related values. Beverly Hills, CA: Sage.

Hymer, S. H. 1976. The international operations of national firms: A study of foreign direct investment. Cambridge, MA: MIT Press.

lammarino, S., \& McCann, P. 2013. Multinational and economic geography: Location, technology, and innovation. Cheltenham: Edward Elgar.

Jaffe, A., Trajtenberg, M., \& Henderson, R. 1993. Geographic localization of knowledge spillovers as evidenced by patent citations. Quarterly Journal of Economics, 108(3): 577-598.

Kahneman, D. 2011. Thinking, fast and slow. New York: Farrar, Straus and Giroux.

Katz, R., \& Allen, T. J. 1982. Investigating the Not Invented Here (NIH) syndrome: A look at the performance, tenure, and communication patterns of $50 \mathrm{R} \& \mathrm{D}$ Project Groups. $R \& D$ Management, 12(1): 7-20.

Kim, T. Y., Delios, A., \& Xu, D. 2010. Organizational geography, experiential learning, and subsidiary exit: Japanese foreign expansions in China, 1979-2001. Journal of Economic Geography, 10(4): 579-597.

Klier, T., \& McMillen, D. P. 2008. Evolving agglomeration in the US auto supplier industry. Journal of Regional Science, 48(1): 235-267. 
Kumaraswamy, A., Mudambi, R., Saranga, H., \& Tripathy, A. 2012. Catch-up strategies in the Indian auto components industry: Domestic firms' responses to market liberalization. Journal of International Business Studies, 43(4): 368-395.

Lorenzen, M. 2007. Social capital and localized learning: Proximity and place in technological and institutional dynamics. Urban Studies, 44(4): 799-817.

Lorenzen, M., \& Mudambi, R. 2013. Clusters, connectivity and catch-up: Bollywood and Bangalore in the global economy. Journal of Economic Geography, 13(3): 501-534.

Malhotra, A., Majchrzak, A., \& Rosen, B. 2007. Leading virtual teams. Academy of Management Perspectives, 21(1): 60-70.

Malmberg, A., \& Maskell, P. 2002. The elusive concept of localization economies: Towards a knowledge-based theory of spatial clustering. Environment and Planning A, 34(3): 429-449.

Mariotti, S., Piscitello, L., \& Elia, S. 2010. Spatial agglomeration of multinational enterprises: The role of information externalities and knowledge spillovers. Journal of Economic Geography, 10(4): 519-538.

Mayer, T., \& Zignago, S. 2011. Notes on CEPII's distances measures (GeoDist). CEPII Working Paper 2011-25.

McCallum, J. 1995. National borders matter: Canada-US regional trade patterns. American Economic Review, 85(3): 615-623.

McCann, P. 2011. International business and economic geography: Knowledge, time and transaction costs. Journal of Economic Geography, 11(2): 309-317.

McCann, P., \& Mudambi, R. 2004. The location behavior of the multinational enterprise: Some analytical issues. Growth and Change, 35(4): 491-524.

McCann, P., \& Mudambi, R. 2005. Analytical differences in the economics of geography: The case of the multinational firm. Environment and Planning A, 37(10): 1857-1876.

Miller, S. R., Thomas, D. E., Eden, L., \& Hitt, M. 2008. Knee deep in the big muddy: The survival of emerging market firms in developed markets. Management International Review, 48(6): 645-665.

Morck, R., \& Yeung, B. 1991. Why investors value multinationality. Journal of Business, 64(2): 165-187.

Moulaert, T., \& Sekia, F. 2003. Territorial innovation models: A critical survey. Regional Studies, 37(3): 289-302.

Mudambi, R. 2002. Knowledge management in multinational firms. Journal of International Management, 8(1): 1-9.

Mudambi, 2008. Location, control and innovation in knowledgeintensive industries. Journal of Economic Geography, 8(5): 699-725.

Mudambi, R., Hannigan, T. J., \& Kline, W. 2012. Advancing science on the knife's edge: Integration and specialization in management Ph.D. programs. Academy of Management Perspectives, 26(3): 83-105.

Mudambi, R., Mudambi, S., \& Navarra, P. 2007. Global innovation in MNCs: The effects of subsidiary self-determination and teamwork. Journal of Product Innovation Management, 24(5): 442-455.

Mudambi, R., \& Navarra, P. 2004. Is knowledge power? Knowledge flows, subsidiary power and rent-seeking within MNCs. Journal of International Business Studies, 35(5): 385-406.

Piscitello, L. 2011. Strategy, location, and the conceptual metamorphosis of the MNE. Global Strategy Journal, 1(1-2): 127-131.

Ramamurti, R., \& Singh, J. 2009. Emerging multinationals in emerging markets. Cambridge: Cambridge University Press.

Rugman, A. 1981. Inside the multinationals. London: Croom Helm.

Rugman, A. 2005. The regional multinationals: MNEs and 'global' strategic management. Cambridge: Cambridge University Press.

Sassen, S. 2000. Territory and territoriality in the global economy. International Sociology, 15(2): 372-393.

Schmitt, A., \& Van Biesebroeck, J. 2013. Proximity strategies in outsourcing relations: The role of geographical, cultural and relational proximity in the European automotive industry. Journal of International Business Studies, 44(5): 475-503.

Schotter, A., \& Beamish, P. 2013. The hassle factor: An explanation for managerial location shunning. Journal of International Business Studies, 44(5): 521-544.
Scott, A. J. 1986. Industrial organization and location: Division of labor, the firm and spatial process. Economic Geography, 62(3): 215-231.

Scott, A. J. 1996. Regional motors in a global economy. Futures, 28(5): 391-411.

Scott, A. J., \& Pope, N. 2007. Hollywood, Vancouver, and the world: Employment relocation and the emergence of satellite production centers in the motion picture industry. Environment and Planning A, 39(6): 1364-1381.

Shenkar, O. 2001. Cultural distance revisited: Towards a more rigorous conceptualization and measurement of cultural differences. Journal of International Business Studies, 32(3): 519-535.

Slangen, A. H. L., \& Beugelsdijk, S. 2010. The impact of institutional hazards on foreign multinational activity: A contingency perspective. Journal of International Business Studies, 41(7): 980-995.

Slangen, A. H. L., \& Hennart, J.-F. 2008. Do multinationals really prefer to enter culturally-distant countries through Greenfields rather than through acquisitions? The role of parent experience and subsidiary autonomy. Journal of International Business Studies, 39(3): 472-490.

Slaughter, M. J. 2004. Insourcing jobs: Making the global economy work for America. Washington DC: The Organization for International Investment.

Steenkamp, J. B. E. M., \& Hofstede, F. T. 2002. International market segmentation: Issues and perspectives. International Journal of Research in Marketing, 19(3): 185-213.

Szulanski, G. 1996. Exploring internal stickiness: Impediments to the transfer of best practice within the firm. Strategic Management Journal, 17(Winter Special Issue): 27-43.

Talbott, S. 2007. The language of nature. The New Atlantis, 15(Winter): 41-76.

Thomas, D. C., Cuervo-Cazurra, A., \& Brannen, M. Y. 2011. From the Editors: Explaining theoretical relationships in international business research: Focusing on the arrows, NOT the boxes. Journal of International Business Studies, 42(9): 1073-1078.

Verbeke, A. 2009. International business strategy. Cambridge: Cambridge University Press.

Wilkins, M. 2004. The history of foreign investment in the United States, 1914-1945. Cambridge, MA: Harvard University Press.

Yeolekar, M. E., \& Mehta, S. 2007. Medical and health research in India: Issues and directions. Journal of Association of Physicians of India, 55(August): 545-546.

Yeung, H. 2005. Rethinking relational economic geography. Transactions of the Institute of British Geographers, 30(1): 37-51.

Zaheer, S. 1995. Overcoming the liability of foreignness. Academy of Management Journal, 38(2): 341-363.

Zaheer, S., Schomaker, M., \& Nachum, L. 2012. Distance without direction: Restoring credibility to a much-loved construct. Journal of International Business Studies, 43(1): 18-27.

\section{APPENDIX}

\section{Space in International Business: An Analysis of} Border and Distance in Papers Published in Journal of International Business Studies (JIBS) since 1990

As part of the background work for editing this special issue, we studied the historical evolution of the spatial dimension in IB. We undertook a Boolean search of the 1291 papers published in the JIBS over the period 1990-2012 and extracted the frequency of the words distance and border. This illustrates the popularity of the distance construct 


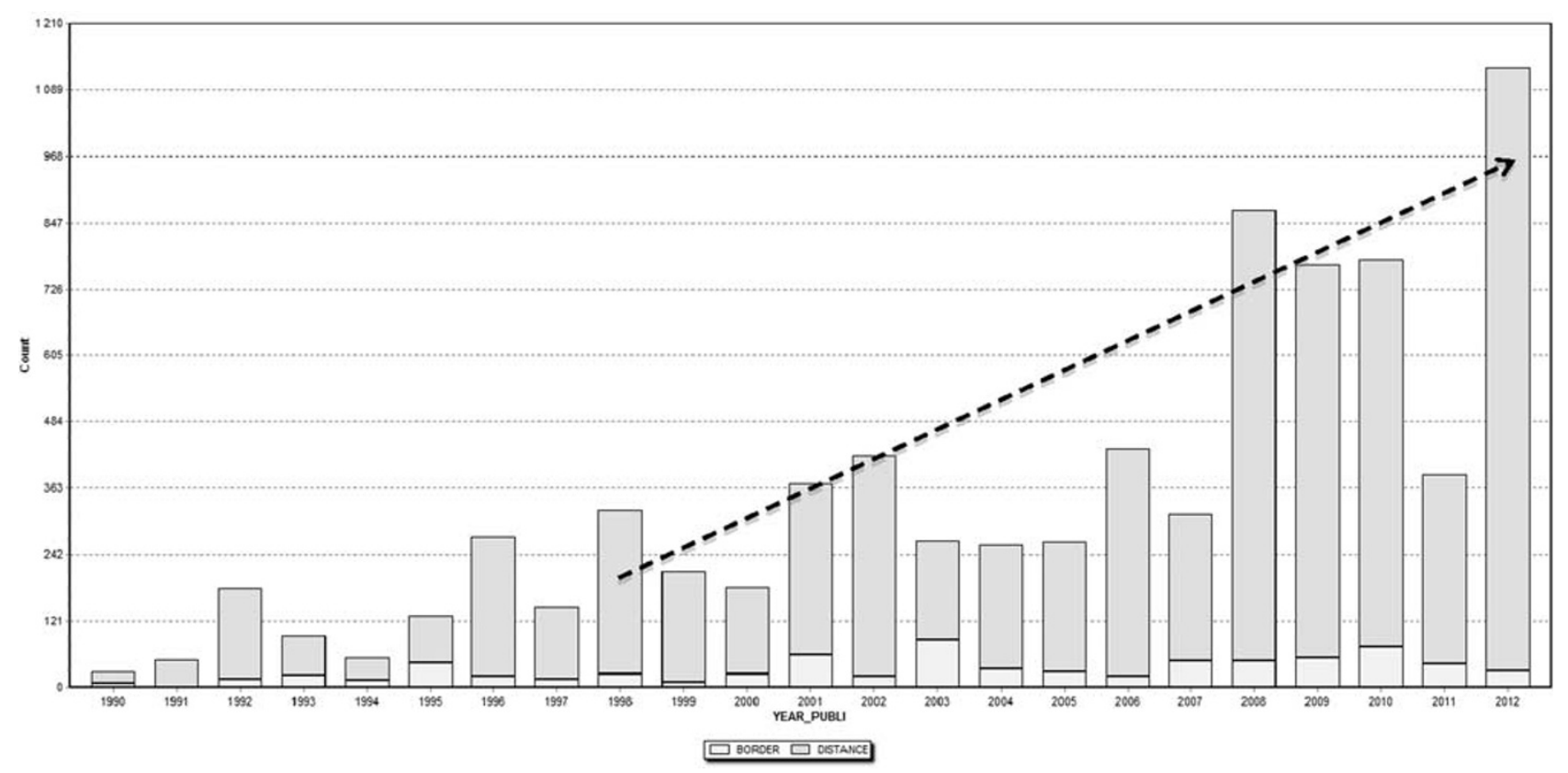

Figure A1 The Dunning effect.

\begin{tabular}{|c|c|c|c|c|c|c|c|c|c|c|c|c|c|c|c|c|c|c|c|c|c|c|c|}
\hline & ळి & ఏ & $\underline{\mathbf{\Phi}}$ & 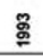 & 兽 & 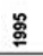 & $\stackrel{\Phi}{\Phi}$ & 兽 & $\stackrel{\varpi}{\Phi}$ & $\stackrel{\$}{\mathbf{g}}$ & స్టి & స్టे & ర్స్ & స్ & อై & స్టి & ఫ్లి & ప్ట్ & : ڤ్ & ర్సి & હัّ & בั & ڤั \\
\hline DISTANCE & 。 & 。 & 0 & 0 & 。 & 0 & 0 & 0 & 0 & 0 & 0 & 0 & 0 & 0 & 0 & 0 & 0 & 0 & & & & & \\
\hline BORDER & . & & 。 & 。 & 。 & o & 。 & - & 。 & - & 。 & 0 & 。 & 0 & $\circ$ & 。 & 。 & 。 & $\circ$ & $\circ$ & 0 & 0 & $\circ$ \\
\hline CULTURAL_DISTANCE & & 。 & 0 & & 。 & - & o & 0 & 0 & $\circ$ & o & 0 & 0 & 0 & 0 & 0 & 0 & 0 & 0 & O & 0 & o & 0 \\
\hline PSYCHIC_DISTANCE & & & & - & & & 0 & - & & - & - & - & 0 & - & & & 0 & ० & 0 & 0 & 。 & $\circ$ & 0 \\
\hline GEOGRAPHIC_DISTANCE & & & & & & & - & & & & - & & - & & - & - & - & 。 & - & - & 。 & $\circ$ & o \\
\hline INSTITUTIONAL_DISTANCE & & & & & & & & & & & & & & & $\circ$ & & & . & 。 & 。 & 。 & - & 0 \\
\hline ECONOMIC_DISTANCE & & & & & & & & & & & & & & - & & & & & & - & - & - & 。 \\
\hline ADMINISTRATIVE_DISTANCE & & & & & & & & & & & & & & & & & & & & & . & . & - \\
\hline
\end{tabular}

Figure A2 The Ghemawat effect.

in IB. ${ }^{3}$ As may be seen in Figure A1, the term border appears with a relatively constant frequency over the entire period. However, the term distance has really taken off.

We point to the relatively structural increase that begins in 1998 and especially from 2001 onwards. We dub this the "Dunning effect," since it is likely to be related to the publication of Dunning's seminal paper on location in 1998 (that subsequently won the JIBS Decade Award in 2008). We note that the increase occurs mainly with the term distance and not border while at the same time virtually all of these studies are really measuring border effects.
This highlights one of the key confusions in what we refer to as first generation IB research on space. This must be cleared up if the field is to progress.

Since the dominant term used in the study of space was distance, we conducted a successor Boolean search to distinguish between different distance dimensions. The results of this exercise are presented in Figure A2. The bigger the bubble, the higher the frequency with which a word appears in JIBS papers in the specified year. The first two lines repeat the results of Figure A1, demonstrating that the Dunning effect expressed itself predominantly in the use of the term distance. 
In 2001, Ghemawat published his highly influential multidimensional distance framework, also referred to as CAGE framework (Ghemawat, 2001). This led IB scholars to view the analysis of space purely in terms of measuring various dimensions of difference-of-means between nations. With regard to these differences, we find that the "Ghemawat effect" expressed itself mainly in a dramatic increase in studies focused on differences between countrylevel measures of culture and psyche (so-called cultural distance and psychic distance). Besides "cultural distance," Ghemawat (2001) also mentioned "geographic," "economic" and "administrative/ institutional" distance. These terms only show up more recently, several years after his 2001 publication.

Both Figures A1 and A2 illustrate our point that while the IB literature on space and geography has increased in volume, it has so far remained stuck in what we refer to as the first generation distance research, failing to come to grips with the distinction between borders and distance and failing to recognize the key role of subnational distance.

\section{The Special Issue Review and Development Process}

The call for papers for this special issue was published in autumn of 2011. By the deadline of
28 November 2012, we received 118 papers, with a third coming from IB scholars, a third from EG scholars and a third from other fields. Of this total, 23 were desk rejected, 10 received a reject and resubmit, and 85 were sent out for review. Many of the rejected papers fell prey to the confusions of first-generation IB research on space highlighted in the analysis above.

Nineteen papers (about 16\%) were given first round revise-and-resubmits and the authors were invited to participate in a Special Issue Conference held at Temple University, Philadelphia, on 27-29 June 2012, just prior to the AIB meetings in Washington DC. The authors received feedback and comments from senior scholars in both IB and EG. None of the senior scholars or commentators had served as reviewers of papers submitted to the special issue. We particularly thank the senior scholars who were so generous with their time in helping us shape the Special Issue: JIBS Editor-inChief John Cantwell (Rutgers), Yves Doz (INSEAD), Mark Lorenzen (Copenhagen Business School), Lucia Piscitello (Politecnico di Milano) and Robert Salomon (New York University).

As always we are deeply in debt to our excellent reviewers. We acknowledge them at the end of the issue as a small token of our gratitude for their generous support of this special issue. 